\title{
Reply to C.D. Richter
}

\author{
Johnathon Liddicoat $\mathbb{1}^{1} \cdot$ Kathleen Liddell ${ }^{1}$ Arlie H. McCarthy ${ }^{2} \cdot$ Stuart Hogarth $^{3} \cdot$ Mateo Aboy $^{1} \cdot$ Dianne Nicol $^{4}$ • \\ Simon Patton $\mathbb{1}^{5} \cdot$ Michael M. Hopkins ${ }^{6}$
}

Received: 4 February 2020 / Accepted: 5 February 2020 / Published online: 17 February 2020

(c) European Society of Human Genetics 2020

\section{To the Editor:}

We thank Dr Richter for responding to our article "Continental drift? Do European clinical genetic testing laboratories have a patent problem?" [1]. Patents, and how they affect genetic testing laboratories and society, are vexed topics. Indeed, researchers from around the world have been studying and debating these topics for almost 20 years (see, e.g. [2, 3]). We, therefore, welcome and value Dr Richter's perspective.

Our study-a large survey-was designed to gather information about whether European law should restrict the availability of gene-related patents. This question was prompted by recent United States Supreme Court decisions that narrowed patentability (for a review, see [4], for quantitative analyses of the decisions, see $[5,6])$. We received data from 158 laboratories, after inviting $~ 806$ to answer a survey about the impact patent rights were having on their clinical and research work.

Based on the survey data, our primary conclusion was that the results do not justify law reform in Europe; watchful monitoring is sufficient in this area. Dr Richter's letter focusses on one of our secondary points, namely that public sector laboratories should be given better IP support. Although law reform is uncalled for, the results showed that

Johnathon Liddicoat

jel68@cam.ac.uk

1 Faculty of Law, Centre for Law, Medicine and Life Sciences, University of Cambridge, Cambridge, UK

2 Department of Zoology, University of Cambridge, Cambridge, UK

3 Department of Sociology, University of Cambridge, Cambridge, UK

4 Faculty of Law, Centre for Law and Genetics, University of Tasmania, Hobart, TAS, Australia

5 European Molecular Genetics Quality Network, Manchester, UK

6 Science Policy Research Unit, University of Sussex, Brighton, UK the level of IP support, in our opinion, is low. Almost half of the laboratories (47\%) said they either did not have any patent support or they sometimes did not have support. The results also showed that the level of support has not improved since a similar survey 10 years ago.

Combined with a low level of IP support, the survey showed that patents had increased effects on laboratories. To recap, compared with a decade ago: (i) laboratories that have refrained from offering a test due to a patent increased from 7 to $15 \%$; (ii) non-profit laboratories that refrained from offering a test due to a patent increased from 4 to $14 \%$; and laboratories that knowingly conducted tests on patented genes or methods increased from 22 to $37 \%$.

We accept that people may have different views about whether better IP support is definitively required, and what form this might take. Below we offer several points to assist future discussions.

Dr Richter argues non-profit laboratories should not be given better IP support. One of his arguments is that it is unclear how support would be provided. In our view, there is no single answer to this question, and this is why we suggested that support is tailored to organisations and conditions, especially as European countries have different systems for providing and reimbursing genetic tests.

Dr Richter notes that a system to apply for grant funding to pay the fees of specialised lawyers to handle litigation would be too slow, and largely unnecessary outside Germany, France and the UK where the risk of patent litigation is low. We agree with these points. In our article, we used the terminology "legal support" in an attempt to distinguish it from "legal advice". To clarify, we would encourage the sort of support that helps laboratories avoid inadvertent infringement of valid patents and excessive worry about patent protection. Primarily, we see this taking place through information channels explaining patent expiration, scope, licensing and outsourcing options.

Dr Richter may assert that this requires expensive legal advice and, therefore, his arguments apply. We largely agree, and, as a result, recommend that laboratories generally 
avoid expensive advice. Instead, many patent issues can be addressed without recourse to solicitors or barristers. For example, laboratory personnel, or general legal counsel employed within hospitals and research organisations, could be taught to use patent databases via online courses. This would enable them to identify, observe and ignore some patents. As we stated in our article, ignoring patents can often be the best strategy. A basic understanding of patent databases would help laboratories identify when it would be appropriate to ignore patents because they are likely invalid, not infringed, or unreasonably licensed. For instance, many patents on DNA sequences are limited to specific techniques or use as drugs, some patents will have lapsed, some patent owners are unlikely to litigate, and some patents are almost certainly invalid in light of prior art the patent examiner was unaware of (but which a laboratory might know).

Other legal support might consist of webinars on exemptions from patent infringement (especially for research), the possibility of non-infringing workarounds, training on negotiating and drafting licences, and how to ensure patent offices consider all the relevant science when they decide if a patent should be granted [7]. Again, these are skills that can be taught in simple short courses, and tasks linked to these skills (e.g. deciding research is covered by an exemption or negotiating a licence) are regularly performed by people without law degrees.

Admittedly, for some issues, more granular information or insurance-backed legal opinions will be important. For example, designing a test that uses similar reagents or a similar method to a patent might risk infringement, but using a different method might not. Training provided to laboratory personnel could help them choose when to elevate their enquiries to this level.

In our article, we suggested that general patent information about tests be disseminated by health departments, patent offices and academic publications. Dr Richter has a different view, stating that "general advice is of limited value" as "any legal advice must be tailored". At the same time, though, he agrees that it would be a good idea for patent office websites to "improv(e) the availability of certain general patent-related information via public channels". In our view, valuable information includes summaries on legal decisions (e.g. the German decision on FLT3, which included outsourcing to avoid infringement) and details of licences (such as those surrounding NIPT). Furthermore, we think patent office websites are not the sole vehicle to disseminate this sort of information.

Dr Richter also commented that "public institutions have specific jobs, and providing specific legal advice is not one of them". The roles of public institutions in our societies are controversial topics that we should all debate. From our perspective, public institutions exist for the public are funded by the public, and are accountable to the public. If, after consideration, society decides that a public institution should provide better IP support, then there is no reason to stop this. Dr Richter says it is not the role of patent offices to provide legal advice on validity or infringement, yet the UK patent office already provides such a public-oriented service for $£ 200$ [8]. Anyone, including publicly funded and privately funded organisations, may use this service.

We agree with Dr Richter that privately and publicly funded laboratories need to consider and handle IP risks, and shoulder the costs of this in their budgets. However, none of our proposals come close to breaching state aid rules, which stop Member States from assisting organisations in ways that unfairly distort competition. Legal issues pervade every public service (GDPR, contracts etc.), and public services normally have access to some legal support. What we suggest are various ways to provide better IP support in simple, education-based ways. Other options exist too, and we hope this discussion about better IP support continues.

\section{Compliance with ethical standards}

Conflict of interest The authors declare that they have no conflict of interest.

Publisher's note Springer Nature remains neutral with regard to jurisdictional claims in published maps and institutional affiliations.

\section{References}

1. Liddicoat J, Liddell K, McCarthy AH, Hogarth S, Aboy M, Nicol $\mathrm{D}$, et al. Continental drift? Do European clinical genetic testing laboratories have a patent problem? Eur J Hum Gen. 2019;27: 997-1007.

2. Merz J, Kriss A, Leonard D, Cho M. Diagnostic testing fails the test. Nature. 2002;415:577-9.

3. Nicol D, Liddicoat J. Do patents impede the provision of genetic tests in Australia? J Aust Health Rev. 2013;37:281-5.

4. Aboy M, Liddell K, Cristina C, Cohen IG, Liddicoat J, Gerke S, et al. How does emerging patent case law in the US and Europe affect precision medicine? Nat Biotechnol. 2019;37:1118-25.

5. Aboy M, Cristina C, Liddell K, Liddicoat J, Jordan M. Was the Myriad decision a 'surgical strike' on isolated DNA patents, or does it have wider impacts? Nat Biotechnol. 2018;36:1146-9.

6. Aboy M, Cristina C, Liddell K, Minssen T, Liddicoat J. Mayo's impact on patent applications related to biotechnology, diagnostics and personalized medicine. Nat Biotechnol. 2019;513:513-8.

7. European Patent Convention, article 115, 5 October 1973 as revised by the Act revising Article 63 EPC of 17 December 1991 and the Act revising the EPC of 29 November 2000 [2001] OJ EPO, Special edition No. 4, p. 55.

8. Patents Act 1977 (UK) c 37, section 74 A; Opinions: resolving patent disputes, UK Government (19 May 2014). https://www.gov. uk/guidance/opinions-resolving-patent-disputes. 